\title{
C-3 Epimerization of 6-Deoxocastasterone in Phaseolus vulgaris
}

\author{
Jung-Yun Hwang, Chan Ho Park, and Seong-Ki Kim

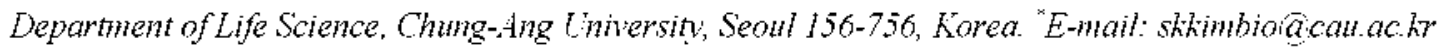 \\ Received September 28, 2006
}

Key Words : Brassinosteroids. 6-Deoxocastasterone. 3-Epi-6-deoxocastasterone. Phaseolus vilgaris

Brassinosteroids (BRs) are steroidal plant hormones. which exert a variety of regulatory effects relevant to plant growth and development. ${ }^{1-5}$ Thus far. over 40 different BRs have been identified throughout the entirety of the plant kingdom. ${ }^{6.7}$ Among the plants so far tested for their BR contents. the inumature seeds of Phaseolus vilgaris represent one of the richest. 11 BRs have been fully characterized from this source. whereas the presence of more than 60 additional unknown BRs has been demonstrated via capillary GC-MS analyses. Our interest in the structure and metabolism of BRs compelled us to conduct a series of investigations into the unkinown BRs contained in the seeds of $P$. vilgaris, by scaling up and employing a sizeable quantity of the plant materials. As a result. we have identified a new BR designated 3-epi-6-deoxoCS. Herein. we report the isolation. characterization. and biogenesis of this BR in Phaseohis seeds.

The ethyl acetate soluble fraction acquired from the Phaseohis seeds (136 Kg) was purified with $\mathrm{SiO}_{3}$. repeated Sephadex LH-20. and charcoal chromatography. ${ }^{8}$ under the guidance of a rice lamina inclination bioassay. Further purification was then conducted wia reversed-phase HPLC (Senshupak Develosil. $20 \times 250 \mathrm{~mm}$ ), ${ }^{8}$ and the resulting HPLC fractions were derivatized to bismethaneboronate (BMB), then analyzed using a capillary GC-MS: HP 5973 mass spectrometer (EI. 70 eV. Hewlett Packard) connected to a 6890 gas chromatograph equipped with a fused silica capillary column $(\mathrm{HP}-5 . \mathrm{DB}-5,0.25 \times 30 \mathrm{~mm})^{10}$
In HPLC fractions 51 and 52. the BMB of a compound evidenced a mass spectrum almost identical to that of the BMB of 6-deoxocastasterone (6-deoxoCS), but the GCretention time of the $\mathrm{BMB}$ compound was longer than that of 6-deoxoCS BMB (Table 1). thereby indicating that the compound was an epimeric 6-deoxoCS. In order to determine the chemical structure of the epimeric 6-deoxoCS. fractions 51 and 52 were purified further via normal-phase HPLC (Senshupak Aquasil $10 \times 200 \mathrm{~mm}$ ) and eluted with chloroform- methanol- $\mathrm{H}_{2} \mathrm{O}(97: 3: 0.1)$ at a flow rate of $3 \mathrm{~mL} /$ $\mathrm{min}^{-1}$. Fractions were collected every minute. Finally the epimeric 6-deoxoCS was isolated in a pure state in HPLC fractions 16 and 17, and verified via $400 \mathrm{MHz}$ proton NMR analysis (JEOL-FX400).

As summarized in Table 2. chemical shifts due to four methyls for C-21, C-24. C-26 or C-27 were observed at $\delta$ 0.85 (d). 0.89 (d). 0.95 (d) and 0.97 (d). Additionally, two proton signals assignable to $\mathrm{H}-22$ and $\mathrm{H}-23$ were detected as broad singlets at $\delta 3.56\left(W_{1: 2}=9 \mathrm{~Hz}\right)$ and $3.73\left(W_{1: 2}=9 \mathrm{~Hz}\right)$. respectively. These signals for the side chain protons were completely identical to those derived from 6-deoxoCS. which indicates that the structure of the side chain in epimeric 6-deoxoCS was identical to that of 6-deoxoCS. However. absorptions for $\mathrm{H}-2(\delta 3.76)$ and $\mathrm{H}-3(\delta 3.97)$ in 6deoxoCS were shifted up-field. at $\delta 3.39$ and 3.59 . respectively: Further, a broad $\mathrm{H}-3$ singlet $\left(W_{1: 2}=10.5 \mathrm{~Hz}\right)$ in 6deoxoCS was altered appearing instead as a broad multiplet $\left(W_{1: 2}=21 \mathrm{~Hz}\right)$. These results suggest that the $\mathrm{C}-3$ equatorial

Table 1. GC-MS/SIM data of endogenous BRs and their metabolites in P. vulgaris

\begin{tabular}{ccl}
\hline Compound $^{a}$ & GC RRt $^{b}$ & Prominent ions (mz, relative intensity \%) \\
\hline 6-deosoCS & 0.769 & $498(\mathrm{M}+, 75), 483(22), 343(20), 314(10), 288(21), 273(100), 213(16), 205(36), 155(26)$ \\
3-epi-6-deosoCS & 1.036 & $498(\mathrm{M}+, 72), 483(18), 343(16), 314(12,288(19), 273(100,205(15), 155(34)$ \\
CS $^{c}$ & 1.000 & $512(\mathrm{M}+, 76), 441(11), 399(8), 358(38), 327(13), 287(34), 155(100)$ \\
Metabolite I $^{d}$ & 1.000 & $512(\mathrm{M}+, 73), 441(10), 399(8), 358(36), 327(13), 287(33), 155(100)$ \\
Metabolite II $^{d}$ & 1.036 & $498(\mathrm{M}+, 72), 483(16), 343(16), 314(12), 288(18), 273(100), 205(13), 155(32)$
\end{tabular}

"Samples were analyzed as bismethanboronate (BMB). ${ }^{\mathrm{R} R \mathrm{Rt}}$ : Relative Retetion time. 'Samples were analyzed by GC-MS. "Samples were analyzed by GC-SIM.

Table 2. $400 \mathrm{MHz}$ 'H-NMR data of 6-deoxoCS and 3-epi-6-deoxoCS (CDCl 3 . TMS as intenal standard)

\begin{tabular}{|c|c|c|c|c|c|c|c|c|c|c|}
\hline \multirow{2}{*}{ Compound } & \multicolumn{4}{|c|}{ Ring protons } & \multicolumn{6}{|c|}{ Side chain protons } \\
\hline & Me-18 & Me-19 & $\mathrm{H}-2$ & $\mathrm{H}-3$ & $\operatorname{Me}(1)$ & $\operatorname{Me}(2)$ & $\mathrm{Me}(3)$ & $\mathrm{Me}(4)$ & $\mathrm{H}-22$ & $\mathrm{H}-23$ \\
\hline 6-deovoCS & $0.67 \mathrm{~s}$ & $0.80 \mathrm{~s}$ & $\begin{array}{c}3.76 \mathrm{br} m \\
\left(w^{1} / 2=21 \mathrm{~Hz}\right)\end{array}$ & $\begin{array}{c}3.97 \mathrm{brs} \\
(\mathrm{w} / 2=10.5 \mathrm{~Hz})\end{array}$ & $0.85 \mathrm{~d}$ & 0.891 & $0.95 \mathrm{~d}$ & 0.971 & $\begin{array}{c}3.56 \mathrm{brs} \\
(J=9 \mathrm{~Hz})\end{array}$ & $\begin{array}{c}3.73 \mathrm{br} . \mathrm{s} \\
(J=9 \mathrm{~Hz})\end{array}$ \\
\hline 3-epi-6-deosoCs & $0.67 \mathrm{~s}$ & $0.86 \mathrm{~s}$ & $\begin{array}{c}3.39 \mathrm{brs} \\
\left(\mathrm{w}^{1} / 2=21 \mathrm{~Hz}\right)\end{array}$ & $\begin{array}{c}3.59 \mathrm{brm} \\
\left(\mathrm{w}^{1} / 2=21 \mathrm{~Hz}\right)\end{array}$ & 0.851 & $0.89 \mathrm{~d}$ & 0.951 & $0.97 \mathrm{~d}$ & $\begin{array}{c}3.56 \mathrm{brs} \\
(j=9 \mathrm{~Hz})\end{array}$ & $\begin{array}{c}3.73 \mathrm{br} \\
(J=9 \mathrm{~Hz})\end{array}$ \\
\hline
\end{tabular}


<smiles>CC(C)C(C)C(O)C(O)[C@H](C)C1CCC2C3CC[C@H]4C[C@H](O)[C@@H](O)CC4(C)C3CCC21C</smiles>

3-epi-6-deoxoCS



6-deoxoCS

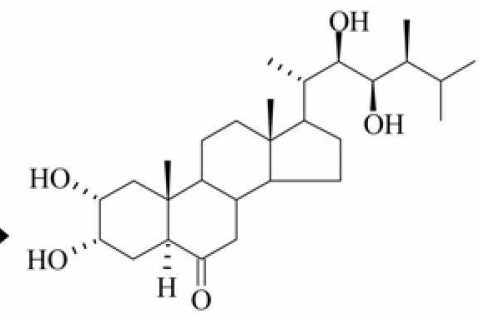

CS

Figure 1. Enzymatic conversions of 6-deoxoCS in Phaseolus vulgaris cells.

proton co-attaching with the $3 \alpha$-hydroxyl in 6-deoxoCS was altered to an axial proton which co-attached with the $3 \beta$ hydroxyl in the epimeric 6-deoxoCS. For this reason. the signal for $\mathrm{CH} 3-19(\delta 0.80, \mathrm{~s})$ in 6-deoxoCS was downshifted to $\delta 0.86$ (s) in the epimeric 6 -deoxoCS. Taken together. the epimer was shown to be 3-epi-6-deoxoCS. (22R. 23R. 24,5)$2 \alpha, 3 \beta, 22,23$-tetrahydroxy-24-methyl-5 $\alpha$-cholestane.

The biogenesis of 3-epi-6-deoxoCS was determined via cell-free enzyme conversion(s). using a cnude enzyme solution prepared from cultured Phaseolus valgaris cells. ${ }^{\text {li }}$ Prior to the enzyme assay's. the presence of CS. the most abundant BR detected in the Phaseolus cells. was assessed in the crude enzy'me solutions. GC-MS/selected ion monitoring (SIM) analy'ses revealed no CS in the solutions (data not shown). thereby indicating that the solutions harbored no detectable amounts of BR. Therefore. non-labeled 6deoxoCS and NADPH $(4.8 \mathrm{mM})$ were added to the enzyme solutions as a substrate and a cofactor. respectively in order to characterize the metabolism of 6-deoxoCS occurring in the plants. After 30 minutes of incubation at $37^{\circ} \mathrm{C}$. the assay mixtures were extracted with ethyl acetate $(1.2 \mathrm{~mL} \times 3)$. The obtained ethyl acetate soluble fractions were then purified by a reversed phase HPLC and analyzed via GC-MS/-SIM following methaneboronation as described previously. ${ }^{13}$

On the full scan GC-MS, an active compound (metabolite 1) in HPLC fractions 19 and 20 generated a mass spectnum and GC-retention time identical with those of authentic CS BMB (Table 1), thereby verifying that 6-deoxoCS had been converted into CS. as had been previously reported ${ }^{11}$ In the GC-SIM analysis an active principle in HPLC fractions 40 and 41 (metabolite II) evidenced prominent ions at $498,483$. 343.332. 314. 288.273.213, 205 and 155, at the same GCretention time as that of the BMB of 3-epi-6-deoxoCS identified in the $P$. vilgaris seeds as mentioned above. This result indicated that 6-deoxoCS was metabolized to 3-epi-6deoxoCS in the Phaseohis cells. Therefore the biogenesis of 3-epi-6-deoxoCS from 6-deoxoCS was confirmed in the Phaseohis cells.

This study is the first. to the best of our knowledge. to identify the new BR. 3-epi-6-deoxoCS in the immature seeds of $P$. vilgaris. Additionally we demonstrated via enzymatic conversion. that 3-epi-6-deoxoCS is generated from 6-deoxoCS within the seeds. Using the same plant material, the co-existence of CS and its 3-epimer. 3-epiCS. has also been demonstrated (data will be published elsewhere). In Onza sativa. Nicotiana tabacum and Catharansus rosens seedlings. the $\mathrm{C}-3$ epimerization of $\mathrm{CS}$ to 3-epiCS has been demonstrated. in feeding experiments utilizing deuterium-labeled CS. ${ }^{12}$ In rice lamina inclination assays, 3epiCS evidences approximately one-fifth less biological activity than is detected with $C . S^{12}$ thereby indicating that 3epiCS nust be considered a product for deactivation. rather than a biosynthetic product. of CS. Although the lower biological activity of 3-epi-6-deoxoCS as compared to 6deoxoCS has yet to be verified, as both BRS are biologically inactive in the bioassay the aforementioned results strongly suggest that 3-epi-6-deoxoCS may be a catabolite of 6deoxoCS in Phaseohis seeds.

Acknowlegement. This research was supported by a grant (PF06304-03) from Plant Diversity Research Center of 21st Century Frontier Research Program funded by Ministry of Science and Teclunology of Korean government.

\section{References}

1. Clouse. S. D.: Sasse. J. M. Amu Rev Plant Plysiol 1998. 10, 1.

2. Altmann. T. Planta 1999. 108. 1.

3. Fukuda. H. Plam Cell 1997.9. 1147

4. Kim. S.-K; Chang, S. C.: Lee, E. J: Chung, W.S.: Kim, Y.-S.; Hwang. S. B.: Lee. J. S. Plant Plnsiol 2000.123 .997$.

5. Oh. M.-H.: Clouse S. D. J. Plant Biol 2003. 46.1.

6. Fujioka. S. In Brassinosteroids: Sakurai. A.. Yokota. T. Clouse. S. D., Eds.; Springer-Verlag: Tokyo, 1999; p 21.

7. Yokota. T. Thends in Plant Science 1997. 2.137.

8. Yokota. T.; Koba, S. Kim. S.-K: Takatsuto. S.; Ihelawa, N.; Sakakubara. M.: Okada. K.: Mori. K.: Takahashi. N. Agric. Biol. Chem 1987.51.1625.

9. Arima. M.: Yokota. T.: Takahashi. N. Plntochentistry 1984. 23. 1587.

10. Kim. T.-W; Hwang, J.-Y; Kim, Y.-S.; Joo, S.-H.: Chang. S. C.; Lee. J. S.: Takatsuto, S.: Kim. S.-K. The Plant Cell 2005. 17. 2397.

11. Suzuki. H.: Fujioka. S.: Takatsuto. S.: Yokota. T.: Murotushi. N.: Sakurai. A. Biosci. Biotechnol Biochem. 1995. 59. 168.

12. Kim. T.-W. Chang. S. C.: Lee, J. S.: Hwang, B.: Talatsuto, S.; Yokota. T.: Kim. S.-K. Phytochemisoy 2004. 656,79. 